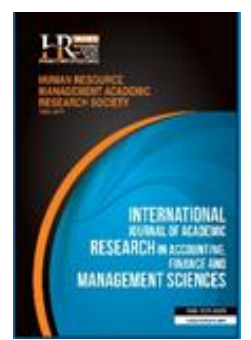

International Journal of Academic Research in Accounting, Finance and Management Sciences

Vol. 10, No.3, July 2020, pp. 97-106

E-ISSN: 2225-8329, P-ISSN: 2308-0337

(C) 2020 HRMARS

www.hrmars.com

To cite this article: Shafai, N. A. Shafai, N. A. (2020). Ownership Structure and Dividend Policy: Malaysian Perspective, International Journal of Academic Research in Accounting, Finance and Management Sciences 10 (3): 97-106.

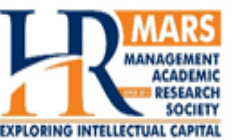

www.hrmars.com

ISSN: $2225-8329$

\title{
Ownership Structure and Dividend Policy: Malaysian Perspective
}

\author{
Nor Anis Shafai ${ }^{1}$, Nor Atikah Shafai ${ }^{2}$ \\ ${ }^{1}$ Universiti Putra Malaysia, Selangor Darul Ehsan, Malaysia ${ }^{1}$ E-mail: anisshafai@gmail.com (Corresponding author) \\ ${ }^{2}$ Universiti Utara Malaysia, Kedah Darul Aman, Malaysia, ${ }^{2}$ E-mail: noratikah@uum.edu.my
}

\begin{abstract}
This research focuses on one of the main corporate decisions that can have a big impact on the feelings of the investor, namely a policy of corporate dividends. This paper examines the relationship between ownership structure and dividend policy in Malaysia over the period 2007-2016 in a sample of 100 top-listed firms from Bursa Malaysia. Generalized Method of Moments (GMM) has been used to analyse the dividend payouts for ownership variables relationship. The empirical results showed there is a positive significant related to concentrated and foreign ownership structure in Malaysia. These suggested that firms claim that foreign investors show more active monitoring on the organization to mitigate the issues with agency and allows the companies to increase the rate of dividend payouts while concentrated ownership may improve a firm's dividend payout by considering large concentrated shareholders to monitor the firm and reduce thus agency problems which align with agency theory.

Key words

Ownership Structure, Dividend Policy, Bursa Malaysia, GMM

\begin{tabular}{|c|c|c|}
\hline Received: & 09 Jul 2020 & (C) The Authors 2020 \\
\hline Revised: & 25 Aug 2020 & Published by Human Resource Management Academic Research Society (www.hrmars.com) \\
\hline $\begin{array}{l}\text { Accepted: } \\
\text { ed Online: }\end{array}$ & $\begin{array}{l}27 \text { Sep } 2020 \\
05 \text { Oct } 2020\end{array}$ & $\begin{array}{l}\text { This article is published under the Creative Commons Attribution (CC BY } 4.0 \text { ) license. Anyone may } \\
\text { reproduce, distribute, translate and create derivative works of this article (for both commercial and } \\
\text { non-commercial purposes), subject to full attribution to the original publication and authors. The full } \\
\text { terms of this license may be seen at: http://creativecommons.org/licences/by/4.0/legalcode }\end{array}$ \\
\hline
\end{tabular}
\end{abstract}

\section{Introduction}

Dividend policy can be referring to the payout policy which firm follows in determining the pattern and size distribution (Baker 2011). It also refers to the payout policy on determining size and rhythm of cash distribution in terms of dividend to the shareholders over the time. Dividend is a distribution of a fragment for a company's earning which is announced by company's board of directors with the input from senior management (Baker, 2009). Besides, payment of dividend also affects the firm's ability to remain earning to feat growth opportunities and the shareholder wealth. Pruitt \& Gitman (1991) said that dividend decisions, investment and financing are related to each other where the management cannot consider dividend policy in segregation from these other decisions. According to (Hakansson, 1982) stated that "dividends continue to flood the empirical world with cash as regularly and as consistently as the sun scorches the desert, and one hard put to characterize this pattern as being founded on irrelevance". Thus, more efforts should be put in place to clarity the picture and uncover the puzzle.

A classic reference by (Jensen \& Meckling, 1976) define the ownership structure as a distribution of equity either in term of votes or capital can be identify as the equity owners. The ownership structure major importance component in corporate governance due to the persuasion incentives of managers and the efficiency of the firms' that they managed.

The literature between a firm's financial policy and ownership structure has been established by previous researchers such (Gul \& Kealey, 1999; Hansen \& Crutchley, 1989; Jensen \& Jensen, 1986). 
Furthermore, companies' decisions based on dividend policy can be influence by corporate ownership structure (Ramli, 2010). Based on Agency theory, there is a conflict of interest between managers and shareholders which is call dividends' agency costs. This situation can be each group has their own interest, regarding on who are the subject of contract and target to satisfy their own interest.

In the financial decision makings, a firm are usually influenced by the firms' policy itself; dividend policy is said to be affected by corporate ownership structure. Past studies that are empirical in nature included those of Al-Gharaibeh (2013); Al-nawaiseh (2013); Miko \& Kamardin (2015); Mossadak, Fontaine, \& Khemakhem (2016); and Sakinc \& Gungor (2015). Corporate theories believe in the influence of agency problem behind the relationship between ownership structure and dividend payout (Jensen, 1986). Furthermore, the literature on the role and function of the modern firm is based on the conjecture of widely dispersed ownership. In the same line, past literature also shows that some contractions of ownership exist among the largest American firms (Demsetz, 1986; Morck et al., 1988).

Prior research on the relationship between ownership structure and dividend policy has largely focused on the developed and emerging market, where the developing countries are abandoning deters further new outlooks (Jabbouri, 2016). Claessens, Djankov, and Lang (2000) stated that nearly every country across East Asia has changed significantly without altering important patterns such as strong family ownership share within the firms. Short, Zhang \& Keasey (2002) found a high explanatory power between ownership structure and dividend policy in the United Kingdom. Furthermore, Sulong \& Ahmed (2011) showed that relationship between ownership structure and dividends has a low explanatory power in Malaysia. The findings from previous studies showed contradicting opinions in developed, developing and emerging markets in terms of explanatory power.

This paper investigates the relationship between Malaysia's ownership structure and dividend policy and attempts to extend and contribute to the existing literature by analysing the effect of ownership structure on dividend policy in Malaysia under the developing market. Moreover, it explores extensively the relation between ownership structure and dividend policy, which is still unexplored in a developing market such as Malaysia. This study is focused on the relationship between ownership structures and dividend policy for listed companies in Malaysia. Therefore, by identify the ownership structure and dividend policy.

\section{Literature review}

\subsection{Ownership Structure}

Ownership structure can be defined as distribution of equity with respect to capital and votes. It was also used to identify the equity owners (Jensen \& Meckling, 1976). In addition, ownership structure is one of the mechanisms which aligned both the interests of the shareholders and the managers (Al-amarneh \& Yaseen, 2014). The legal and ownership structure of a firm is based on the percentage of owned share. Moreover, ownership structure was also important in the dividend policy since it affected the motivations of managers and the firms' efficiency as a whole. Furthermore, dissociate between management and ownership is an agency relation arisen between management and shareholders where management is an agent to the shareholders in managing their money (Manneh \& Naser, 2015). Nevertheless, ownership structure largely depended on agency problem such as dispersed owners with little stakeholders in organization does not worry on the strictly monitor the actions of managers (Altoumy, 2015). The different ownership categories in a firm setting may have different interest including the authority and power (Kulathunga \& Azeez, 2016).

\subsection{Agency theory}

Previous study by Miller \& Modigliani (1961) assumed no conflict between the managers and shareholders. Conversely, the assumption was impractical as the managers and the investors may not have similar interest. Shareholders could experience the agency cost resulted from potential conflicting interests of the manager and shareholder. Agency cost is known as internal cost that must be paid to an agent who acted on behalf of a principal. The costs arose due to the conflicts of interest between shareholders and management. Referring to Short et al. (2002), dividend policy played an important role in minimizing agency cost resulting from the conflicting interest of both parties. Majority of shareholders wanted the 
owner to manage the firm which led to increasing shareholder value. Otherwise, the management required the firm to maximise their personal power and wealth that were beyond the concern of the shareholders.

\subsection{Signaling theory}

In a firm, Miller and Modigliani model assumed that information was equally available for insider and outsider. However, information regardless of the firms value was mostly acquired by the manager that cannot be excessed by outsider (Robinson, 2006). Besides, signaling model argued the presence of asymmetric information between managers and shareholders which consummated the gaps between these issues. The information gap explained the signal provided by the dividends announcement used by manager which carried valuable information for investors regarding on the future performance of the firm. Announcement on an increase in dividend payouts indicated positive future prospects known as dividend signaling theory. The manager could decide on the level of dividend payout and the internal information to be conveyed to the external inventors (Bhattacharya, 1979). According to Al-malkawi (2008), positive reaction regarding on the share price will rise based on the shareholders interpretation on increasing dividend payment as a signal of future profitability. Otherwise, share price may react unfavourably as the dividend payout ratio decreased.

\subsection{Concentrated ownership and dividend policy}

The number of share held by the holding the largest 5 shareholders of a firm is as measured the concentrated ownership structure. Furthermore, decision on dividend policy and all other important corporate policies were based on the discretion of concentrated person. Moreover, the concentrated shareholders had considerable influence in a business and significant control which weakened the classic conflicts between shareholders and managers (Al-qahtani, 2017) or reduced the agency cost problem.

Miko \& Kamardin (2015) examines the effect of ownership structure on the corporate dividend policy in the line with agency context. Sample of their studied is eight conglomerate firms in Nigeria for a period of 10 years starting 2001 until 2010. The authors supported the idea of higher block-holders shareholdings induced greater dividend payout where the empirical results depict positive association between dividend payout. The authors suggested the use of dividend policy by managers to expropriate the shareholder wealth.

Meanwhile, concentrated owners with higher expected future earnings could postpone their current dividend payment in case the concentrated ownership might negatively influence the dividend payment Gonzalez et al. (2016) investigated the effect of concentrated ownership on dividend of Latin America publicly traded firms using a period of 2007 until 2013. They found significant negative correlation between highly concentrated ownership and the presence of individual or family related largest shareholders towards the dividend payout. Similarly, Berzins et al. (2012) observed a negative relationship between private block holders and firms' cash dividends.

\section{H1: Concentrated ownership is positively associated with dividend policy}

\subsection{Managerial ownership and dividend policy}

The proportion of stock owned by the board of directors and managers from the total outstanding share in a firm for that year represented the managerial ownership. Meanwhile, Shah et al. (2011) defined managerial ownership as the percentage of share held by the board of directors divided by the total number of shares. The role of managers in ownership had been argued differently among researches. The managerial ownership has been on the heads of managers which can help eliminate the problem of free cash flow and support the mutual interest on shareholders and management. Hence, dividend payments in the firms with higher in managerial ownership will be lower than other firms.

According Kulathunga \& Azeez (2016) investigated the association between ownership structure and dividend policy of listed firms in Colombo Stock Exchange for period 2006 until 2014. The authors found negative impact of insider on the level of dividend paid. Thus, this supported the view that insider may become entrenched and attempted to extract private benefits instead of paying cash dividends to other shareholders. 
According to Obaidat (2018), investigated the effect of ownership structure on the dividend policy for emerging market by using listed firms from Amman Stock Exchange for the period 2014 until 2016. He found out that the managerial ownership was also found to have a positive relationship between dividend per share and their justification is based on previous study by (Al-qahtani, 2017) where they argued that high percentage of managerial ownership leads to an opportunistic behaviour among the board directors which leads to high levels of dividend to control this behaviour.

H2: Managerial ownership is negatively associated with dividend policy

\subsection{Institution ownership and dividend policy}

Institutional ownership was the percentage of share owned by institutional investors such banks, insurance firms, pensions funds, investment firms, financial institutions and other nominee firms under the mentioned institutions (Al-Gharaibeh, 2013). Institutional ownership may act as a monitoring device on the corporation's managers (Shleifer \& Vishny, 1986) where the institutional block holders such financial institutions, banks, pension funds, insurance firms, investment banks and mutual funds could act as a monitoring mechanism for the firm's management.

Al-nawaiseh (2013) study a sample of 62 industrial listed firm from ASE from 2000 until 2006. He adopted Tobit model and found significantly positive relationship between the institutional ownership and dividend policy which supports the view that institutional investors favour dividend income over capital gains. In addition, Kulathunga \& Azeez (2016) examined the relationship between the different types of ownership structure and dividend policy for firms listed in Colombo Stock Exchange over the period of 2006 until 2014. Their results indicated a negative association between institutional, managerial and dividend policy. The institutional, managerial and concentrated ownership are aligned with the signaling, free cash flow and agency theory explanations for dividend payouts.

H3: Institutional ownership positively associated with dividend policy

\subsection{Foreign ownership and dividend policy}

Investors from foreign countries usually strictly monitored the managerial activities as they were more interested in the corporate decision. Foreign ownership was known as percentage of share owned by foreign investors that were mostly invested to pay dividend. Foreign ownership had important impact on the dividend policy of the concerned firm (Chai, 2010). Foreign investors are becoming important and influential in stock market as many countries nowadays allowed foreigners investors to invest in their stock market. Liljeblom et al. (2015) studied the relation between corporate governance mechanism and dividend policy in Russian firms. The authors found negative and significant association between the foreign ownership and the dividend payout at 1 percent level. This result was in line with the negative effects of large owners on corporate governance.

Setiawan et al. (2016) examine the effect of ownership structure on dividend policy using Indonesian context for the period of 2006 until 2012. The result shows that foreign-controlled firms have a positive effect on dividend payout and the authors argued that foreign owners firms has to pay more dividend as they prefer to earn higher returns in dividend compared to reinvest.

\section{H4: Foreign ownership positively associated with dividend policy}

\subsection{Government ownership and dividend policy}

Government or state ownership considered the percentage owned by government such central, federal, state, regional and local (Al-Kuwari, 2009; Wang et al., 2011). In addition, greater ownership by the government meant more mechanisms to reduce agency conflicts instead of the dividend mechanism. This is due to government's role as an external monitoring party. Some inconsistent opinion, stated that state firms are generally inefficient as they tend to use firms to pursue political objective and losses result in massive shortages of their economies (Al-Najjar \& Kilincarslan, 2016).

Wang et al. (2011) examined the impact of state ownership on the dividend policy for Chinese firms over the period of 1998 until 2008. The authors found increasing state ownership would also increase the dividend payout among dividend paying firms and the possibility dividend payment. 
Al-Najjar \& Kilincarslan (2016) adopted random effects logit and tobit regression in order to investigate the impact of ownership structure on dividend policy of listed firms in Turkey. The empirical results show that state ownership associated with a less likelihood of paying dividends. The result due to major reforms in 2003 by Turkish government including enhanced privatisation programme. Thus, this situation provide more efficient ownership structure which is better for corporate governance, transparency and disclosure practise in Turkey. Therefore, state ownership that involved with less need for dividend and capital market monitoring.

H5: Government ownership positively associated with dividend policy

\section{Methodology of research}

the study adopts the model from previous studies (San Martín Reyna, 2017), (Setiawan et al., 2016), and (Jebaraj et al., 2016). Some modifications have been made on the original models to achieve the intended objectives of the study. The dynamic panel data model technique is adopted for data analysis to analysed the ownership structure of dividend policy using dividend payout as dependent variable and concentrated, managerial, institution, foreign and government ownerships as the independent variables using dynamic panel model where the distributed lagged values of independent variables are included as independent variables (Bostanci \& Kadioglu, 2018).

\subsection{Data collection and sample size}

The sample firms are selected from listed firms in the stock exchanges of Malaysia (Bursa Malaysia) and this study uses a sample from the top 100 firms and the data collected for ten years form 2007 until 2016. The sample are based on market capitalization so as to show the importance of firm size as a basic determinant of various characteristics. Selection based on higher market capitalisation has also been used by previous studies (Al-qahtani, 2017; Yusof \& Ismail, 2016; Mohd et al., 2012). The main reason for selecting large firms is because of the huge propensity of these firms to pay dividends to their shareholders (Yusof \& Ismail, 2016). Folowed by Gonzalez \& Gonzalez (2012) and Wiwattanakantang (1999), banks and financial institutions are excluded since the financial decisions and rules on dividend policy they undertake (such as different role in capital market, tighter sector regulation and accounting perspective) are different from the rest of the sectors. Furthermore, financial sectors are heavily regulated and require a separate review from the other sectors. Thus, in order to minimise survivorship bias, financial institutions and missing data are all excluded in the sample. Consequently, out of 100 listed companies, only 67 were in this sample after extracting these firms. The data where anaylsed using tools from Stata version 13.0.

\subsection{Model Specification}

This model is reliable in analysing the relationship between ownership structure and dividend policy of firms in Malaysia. A dynamic panel regression is used to capture the relationship between ownership structure and dividend payout. This analysis calculates the dynamic relationship by integrating the lagged distribution dividend ratio (DPRt-1) into the model. Hence, the empirical model is extended as below:

$$
D P R_{i t}=\alpha_{i}+\beta 1 D^{2} R_{i t-1}+\beta 2 C O N C_{i t}+\beta 3 M A N_{i t}+\beta 4 I N S_{i t}+\beta 5 F O R_{i t}+\beta 7 G O V_{i t}+\varepsilon_{i t}
$$

Where;

$\mathrm{DPR}_{\text {it }} \quad=$ Ratio of dividend per share to earnings per share of the firm $\mathrm{i}$ in the time of $\mathrm{t}$

$D P R_{i t-1}=$ Lagged dividend payout ratio of the firm $i$ in the time of $t$

CONC $_{\text {it }}=$ Percentage of share of firm $\mathrm{i}$ held by the largest 5 shareholders in the time of $\mathrm{t}$

MAN $_{i t}=$ Percentage of share of firm $\mathrm{i}$ held by directors and managers in the time of $\mathrm{t}$

$\mathrm{INS}_{\text {it }} \quad=$ Percentage of share of firm $\mathrm{i}$ held by financial institutional in the time of $\mathrm{t}$

FOR $_{\text {it }} \quad=$ Percentage of share of firm $\mathrm{i}$ held by foreign investors in the time of $\mathrm{t}$

$\mathrm{GOV}_{\text {it }} \quad=$ Percentage of share of firm $\mathrm{i}$ held by government in the time of $\mathrm{t}$

\subsection{Variables and measurements}

Dependent variable: The dividend payout ratio (DPR) as a proxy to indicate a firm's payout policy since management might influence the profit and dividend ratio. Furthermore, dividend payout ratio also 
measures the ratio of dividend paid in relation to an internal performance indicator. Hence, it is the most appropriate ratio to be applied for fundamental analysis and can be used by managers within the firm and outside analysts.

Independent variables: They can be categorised according to the different types of ownership structure. Rus and Abdullah (2005) claimed that many independent variables in previous empirical works did not depend on any solid underlying theory. However, these ownership structures are based on the predictive success and their frequent usage in previous studies.

(1) Concentrated ownership (CONC) is measured by the percent of shares owned by five (5) largest shareholders. The dominant shareholders can form alliance to control the firm and confiscate the minority shareholders. (2) Managerial ownership (MAN) is calculated as a percentage of managerial ownership (proportion of managers, executives, directors and their families) divided by the total equity of the firm. Results from different studies showed manager's role in the ownership structure where the management and shareholders interest may be adequately advocated through managerial ownership, thus minimising the conflict of interest. (3) Institutional ownership (INS) is measured by the percentage of institutional ownership (banks, insurance firms, investment institutions, pension funds, and other large-scale financial institutions) divided by total equity of the firm. The important part of institutional ownership is in monitoring the firm's management using their expert knowledge and accounts of huge investments. (4) Foreign ownership (FOR) is calculated as the percentage of foreign ownership divided by total equity of the firm. Based on the outcome model by Porta et al. (2000), good corporate governance mechanisms by foreign-controlled firms may lead to higher dividends. Moreover, protecting their investment requires higher incentives to observe the corporate activities. (5) Government Ownership (GOV) represents the degree of ownership by the government or state, measured by the total shares held by state or government institution divided by the total shares. Higher government ownership is one mechanism to reduce the agency conflicts in addition to dividend mechanism.

\section{Empirical results}

\subsection{Descriptive Analysis}

The summary of the results in the Table 1 for Malaysian firms shows that the average value for dividend payout ratio (DPR) is $\mathbf{4 3 . 2 4}$ percent which represents the average amount of dividend paid for the ten-year period. The descriptive result for concentrated ownership (CONC) is 71.2 percent indicating that 71 out of 100 shares are held by the largest shareholders in Malaysian listed firms. Managerial ownership (MAN) shows a mean of 8.29 percent. The maximum amount of managerial ownership is 99.22 percent. According to a firm's annual report, the amount of managers and directors holding shares in the firm is almost 100 percent and the minimum amount is zero. Furthermore, results of institutional ownership (INS) shows that 20.25 percent of ownership is in the hands of institutional shareholders from insurance firms, pension funds, mutual funds, and units trust financial institutions. Foreign ownership (FOR) holding in the sampled firms ranges from zero and to 82.03 percent. The mean value for foreign ownership is 15.86 percent with a standard deviation of 19.84 percent. For the government ownership (GOV), the average value is 8.48 percent with a standard deviation of 12.83 percent.

Table 1. Descriptive analysis

\begin{tabular}{lcccc}
\hline Variables & Mean & Std Dev & Max & Min \\
\hline DPR & 43.24 & 27.44 & 100 & 0 \\
CONC & 71.2 & 24.41 & 97.28 & 0 \\
MAN & 8.29 & 17.12 & 99.22 & 0 \\
INS & 20.25 & 20.15 & 91.83 & 0 \\
FOR & 15.86 & 19.84 & 82.03 & 0 \\
GOV & 8.48 & 12.83 & 70.18 & 0 \\
\hline
\end{tabular}

Notes: All the explanatory variables in the model are: Dividend payout ratio (DPR), concentrated ownership (CONC), managerial ownership (MAN), institutional ownership (INS), foreign ownership (FOR), and government ownership (GOV) 


\subsection{Correlation analysis}

Table 2 shows a positive correlation between dividend payout ratios (DPR) with the four types of ownership: concentrated (CONC), institutional (INS), foreign (FOR), and government (GOV) for Malaysian listed firms. The results suggest that dividend payout ratio is likely to increase with the increase of all the variables. However, managerial ownership (MAN) is negatively correlated with dividend payout ratio.

Table 2. Correlation analysis

\begin{tabular}{lllllll}
\hline & DPR & CONC & MAN & INS & FOR & GOV \\
\hline DPR & 1.0000 & & & & & \\
CONC & 0.2273 & 1.0000 & & & & \\
& $(0.0000)$ & & & & & \\
MAN & $-0.1048^{* * *}$ & 0.2024 & 1.0000 & & & \\
& $(0.0001)$ & $(0.1103)$ & & & & \\
INS & $0.0826^{* *}$ & $0.3363^{* * *}$ & -0.0076 & 1.0000 & & \\
& $(0.0979)$ & $(0.0000)$ & $(0.7502)$ & & & \\
FOR & $0.3910^{* * *}$ & $0.2250^{* * *}$ & $-0.0533^{* *}$ & $0.0115^{* *}$ & 1.0000 & \\
& $(0.0000)$ & $(0.0000)$ & $(0.0022)$ & $(0.0365)$ & & \\
GOV & $0.2067^{* * *}$ & $0.2787^{* * *}$ & $-0.1738^{* * *}$ & $0.2549^{* * *}$ & 0.0128 & 1.0000 \\
& $(0.0000)$ & $(0.0000)$ & $(0.0004)$ & $(0.0000)$ & $(0.1614)$ & \\
\hline
\end{tabular}

Notes: (1) All the explanatory variables in the model are: Dividend payout ratio (DPR), concentrated ownership (CONC), managerial ownership (MAN), institutional ownership (INS), foreign ownership (FOR), and government ownership (GOV). (2) The rule of thumb $<0.8$ (Malhotra et al., 2006). (3) *,** and ${ }^{* *}$ depict $10 \%, 5 \%$ and $1 \%$ levels of significance respectively. Significance levels are in parenthesis.

\subsection{Dynamic Panel Model: Ownership Structure}

This section introduces and explains the outcomes of the Generalised Moments System (GMM) used, which estimates the dynamic panel model for all sample companies from 2007 through 2016. Table 3 presents the result of ownership structure effect on dividend payout ratio. The table shows results on both one-step and two-step of Different GMM estimators. In this regards, testing the variables draws a number of conclusions from the two-step Different GMM estimators. This model has pass the Sargan test of over identifying restrictions, and for autocorrelation test (Arellano-Bond).

The results of difference GMM (two-step) for Malaysia shows that the lagged dependent variable has a significant and positive impact at the 1 percent level. The independent variables have positive and significant relationships with concentrated ownership (CONC) and dividend payout ratio (DPR), suggesting that highly-concentrated firms respond well to the firm's progress and development. Other factors such as managerial (MAN) and foreign (FOR) ownerships have positive impacts, while institutional (INS) ownership has a negative impact on dividend payout ratio. All the three variables are significant at the 5 percent level.

Table 3. Result of Different Dynamic Panel GMM for Ownership Structure

\begin{tabular}{ccc}
\hline \multicolumn{3}{c}{ Malaysia } \\
\hline & Difference GMM & \\
\hline OPR $(t-1)$ & $0.331^{* *}$ & Two Step \\
\hline \multirow{2}{*}{ CONC } & {$[0.1311]$} & $0.28^{* * *}$ \\
& $0.185^{* *}$ & {$[0.053]$} \\
MAN & {$[0.086]$} & $0.138^{* * *}$ \\
& 0.078 & {$[0.037]$} \\
INS & {$[0.159]$} & $0.128^{* *}$ \\
& -0.172 & {$[0.059]$} \\
FOR & {$[0.174]$} & $-0.12^{* *}$ \\
& 0.2 & {$[0.052]$} \\
GOV & {$[0.158]$} & $0.153^{* *}$ \\
& -0.044 & {$[0.071]$} \\
& {$[0.312]$} & -0.014 \\
& & {$[0.112]$} \\
\hline
\end{tabular}




\begin{tabular}{ccc}
\hline$A R(1)$ & - & 0.013 \\
$A R(2)$ & - & 0.873 \\
Sargan test & 0.518 & 0.685 \\
\hline
\end{tabular}

Notes:

(1) All the explanatory variables in the model are: Dividend payout ratio (DPR), concentrated ownership (CONC), managerial ownership (MAN), institutional ownership (INS), foreign ownership (FOR), and government ownership (GOV) (2) Values in [] is standard error (3) The dependent variable and all explanatory variables are in ratios and log values. (4) $* * *, * *$ and $*$ denotes significant at $1 \%, 5 \%$ and $10 \%$, respectively. Standard errors are reported in parenthesis

\subsection{Robustness Test: Ownership Structure}

To test for the robustness of the result presented in the above section, the model is tested using the System GMM (two-step). Table 4, shows the result of the Sargan test on the instrument validity and the test of Arellano-Bond on the autocorrelation. All three countries pass both tests. There is no second-order of correlation in the error terms, the instruments are correctly specified for the three countries. The result shows the specified model applied to analyse the relationship between ownership structure and divided policy. The lagged dividend payout ratio $\left(D^{2} R_{(t-1)}\right)$ for the three countries generate almost the same result as in Table 3 in terms of signs and coefficient values. The coefficients for both estimations are positive and significant at 1 percent level. Moreover, coefficients for other variables also closely resemble the result in the base case study.

Concentrated ownership (two-step) is found to have a positive effect on dividend payout for Malaysia with the correct sign of and effect at the 1 percent level. The result suggests that, concentrated ownership may improve a firm's dividend payout by considering large concentrated shareholders to monitor the firm and reduce thus agency problems. Meanwhile, for managerial ownership it shows that there is positive but insignificant impact on dividend policy. This is due to the managerial ownership (twostep) is not significantly associated with dividend payout because the managers and directors having a small percentage of ownership, and thus cannot influence much of the decisions on dividend policy. In particular, Malaysia show negative insignificant relationships for institutional ownership and dividend payout ratio. This suggests that institutional ownership (two-step) exerts no impact and does not increase the dividend payout ratio for Malaysian. As for foreign ownership (two-step), Malaysia is at the 5 percent level with positive and significant at different levels. In other words, increasing foreign ownership should alleviate the level of dividend distribution. Finally, the government ownership (two-step) Malaysia show a positive but an insignificant relation between government ownership and dividend payout suggesting that this country had less intervention from the government.

\section{Conclusions}

The study explores the dividend-policy ownership structure of listed companies in Malaysia. The study uses Bursa Malaysia's top 100 listed companies from 2007 to 2016 to determine ownership structure in Malaysia, an emerging market where relatively less empirical data is available. In addition, using the GMM estimate, the analysis found that:

- Lagged dividend payout ratio estimations are positive and significant at 1 percent level.

- Concentrated ownership has positive and significant effect at 1 percent level on dividend policy.

- Managerial ownership has positive but not significant effect on dividend policy.

- Institutional ownership has positive but not significant effect on dividend policy.

- Foreign ownership has positive and significant effect at 5 percent level on dividend policy.

- Government ownership has positive but not significant effect on dividend policy.

\section{Theory implication and limitation}

One of the agency theory conflicts is the miscommunication between the directors and the shareholders of the company. A clear plan can sometimes not be drawn up by the board of directors. As a rational, the dividend policy does not please the owners and this produces a distrustful climate. This can be 
overcome by aligning policy with other shareholders ' needs. This will significantly enhance the quality of organizational performance and personal goal accomplishment. Meanwhile, the main limitations to be addressed here are related to the number of firms as this study only adopted the top 100 listed firms from each countries and does not cover the financial sector. Moreover, the financial data were collected from several data sources with relatively different degree of validity and measurement.

\section{References}

1. Al-Gharaibeh, M. (2013). The Effect of Ownership Structure on Dividends Policy in Jordanian Companies. Interdisciplinary Journal of Contemporary Research in Business, 4(9), 769-796.

2. Al-Kuwari, D. (2009). Determinants of the Dividend Policy in Emerging Stock Exchanges: The Case of GCC Countries. Global Economy \& Finance Journal, 2(2), 38-63.

3. Al-malkawi, H. N. (2008). Factors Influencing Corporate Dividend Decision: Evidence from Jordanian Panel Data. International Journal of Business, 13(2), 177-195.

4. Al-Najjar, B., \& Kilincarslan, E. (2016). The Effect of Ownership Structure on Dividend Policy: Evidence from Turkey. Corporate Governance: The International Journal of Business Society, 16(1), 135-161.

5. Al-Najjar, Basil, \& Kilincarslan, E. (2016). The Effect of Ownership Structure on Dividend Policy: Evidence from Turkey. Corporate Governance (Bingley), 16(1), 135-161. https://doi.org/10.1108/CG-092015-0129

6. Al-qahtani, T. H. (2017). The Impact of Ownership Structure on Dividend Policy the Evidence from Saudi Arabia. Journal of Emerging Issues in Economics, Finance and Banking (JEIEFB), 6(1), 2187-2202.

7. Berzins, J., Bøhren, $\varnothing$., \& Stacescu, B. (2012). Stockholder Conflicts and Dividend Payout. SSRN Electronic Journal, 2-23. https://doi.org/10.2139/ssrn.2146944

8. Bhattacharya, S. (1979). Imperfect Information, Dividend Policy, and "The Bird in the Hand" Fallacy. The Bell Journal of Economic, 10(1), 259-270.

9. Bostanci, F., \& Kadioglu, E. (2018). Determinants of Dividend Payout Decisions : A Dynamic Panel Data Analysis of Turkish Stock Market. International Journal of Financial Studies, 4(93), 1-16. https://doi.org/10.3390/ijfs6040093

10. Chai, D. H. (2010). Foreign Corporate Ownership and Dividends. University of Cambridge, 401(401), 1-40.

11. Claessens, S., Djankov, S., \& Lang, L. H. (2000). The Separation of Ownership and Control in East Asian Corporations. In Journal of Financial Economics (Vol. 58). https://doi.org/10.1016/S0304405X(00)00067-2

12. Gonzalez, M., Molina, C. A., Pablo, E., \& Rosso, J. W. (2017). The Effect of Ownership Concentration and Composition on Dividends: Evidence from Latin America. Emerging Markets Review, 30, 1-18. https://doi.org/10.1016/j.ememar.2016.08.018

13. Gonzalez, V. M., \& Gonzalez, F. (2012). Firm Size and Capital Structure: Evidence Using Dynamic Panel Data. Applied Economics, 10(1), 38-48. https://doi.org/10.1111/1365-2664.12319

14. Gul, F. A., \& Kealey, B. T. (1999). Chaebol, Investment Opportunity Set and Corporate Debt and Dividend Policies of Korean Companies. Review of Quantitative Finance and Accounting, 13(4), 401-416. https://doi.org/10.1023/A:1008397808221

15. Hansen, R. S., \& Crutchley, C. E. (1989). Agency Theory of Corporate Ownership, Managerial Corporate Dividends Leverage , and Corporate Dividends. Financial Management, 18(4), 36-46.

16. Jabbouri, I. (2016). Determinants of Corporate Dividend Policy in Emerging Markets: Evidence from MENA Stock Markets. Research in International Business and Finance, 37, 283-298. https://doi.org/10.1016/j.ribaf.2016.01.018

17. Jebaraj, S., Shaista, B., \& Helen, W. (2016). Family Ownership and Dividend Payout in Malaysia. International Journal of Managerial Finance, 12(3), 314-334.

18. Jensen, M. C., \& Jensen, B. M. C. (1986). Agency Costs of Free Cash Flow, Corporate Finance, and Takeovers. The American Economic Review, 76(2), 323-329. https://doi.org/10.2139/ssrn.99580

19. Jensen, M. C., \& Meckling, W. H. (1976). Theory of The Firm: Managerial Behavior, Agency Costs and Owership Srtucture. Journal of Financial Economics, 3, 305-360. 
20. La Porta, R., Lopez-de-Silanes, F., Shleifer, A., \& Vishny, R. W. (2007). Investor Protection and Corporate Governance. In Corporate Governance and Corporate Finance: A European Perspective (Vol. 58, pp. 91-110). https://doi.org/10.4324/9780203940136

21. Liljeblom, E., Maury, B., Liljeblom, E., \& Maury, B. (2016). Shareholder Protection, Ownership, and Dividends: Russian Evidence. Emerging Markets Finance and Trade, 52(10), 2414-2433. https://doi.org/10.1080/1540496X.2015.1073991

22. Miko, N. U., \& Kamardin, H. (2015). Ownership Structure and Dividend Policy of Conglomerate Firms in Nigeria. Academic Journal of Interdisciplanary Studies, 4(2), 279-286. https://doi.org/10.5901/ajis. 2015.v4n2p279

23. Miller, M. H., \& Modigliani, F. (1961). Dividend Policy, Growth, and the Valuation of Shares. The Journal of Business, 34(4), 411-433.

24. Mohd, N., Abdullah, H., Ahmad, Z., \& Roslan, S. (2012). The Influence of Ownership Structure on the Firms Dividend Policy Based Lintner Model. International Review of Business Research Papers, 8(6), 7188.

25. Obaidat, A. N. (2018). Ownership Structure and Dividends Policy: Emerging Market Evidence. International Business Research, 11(6), 65-72. https://doi.org/10.5539/ibr.v11n6p65

26. Pruitt, S. W., \& Gitman, L. J. (1991). The Interactions between the Investment, Financing, and Dividend Decisions of Major U.S. Firms. Financial Review, 26(3), 409-430.

27. Ramli, N. M. (2010). Ownership Structure and Dividend Policy: Evidence from Malaysian Companies. International Review of Business Research ..., 6(1), 170-180.

28. Robinson, J. (2006). Dividend Policy among Publicly Listed Firms in Barbados. Journal of Eastern Caribbean Studies, 30, 367-385.

29. Rus, R. M., \& Abdullah, N. A. H. (2005). An Empirical Investigation of Failing Companies in an Emerging Capital Market.

30. San Martín Reyna, J. M. (2017). Ownership Structure and its Effect on Dividend Policy in the Mexican Context. Contaduria y Administracion, 62(4), 1199-1213. https://doi.org/10.1016/j.cya.2015. 12.006

31. Setiawan, D., Bandi, B., Kee Phua, L., \& Trinugroho, I. (2016). Ownership Structure and Dividend Policy in Indonesia. Journal of Asia Business Studies, 10(3), 230-252. https://doi.org/10.1108/JABS-052015-0053

32. Shah, Z. S. A., Ullah, W., \& Hasnain, B. (2011). Impact of Ownership Sturcture on Dividend Policy of Firm. 2010 International Conference on E-Business, Management and Economics IPEDR, 3, 22-26.

33. Shleifer, A., \& Vishny, R. W. (1986). Larger Shareholders and Corporate Control. The Journal of Political Economy, Vol. 1, pp. 461-488.

34. Short, H., Zhang, H., \& Keasey, K. (2002). The Link between Dividend Policy and Institutional Ownership. Journal of Corporate Finance, 8(2), 105-122.

35. Sulong, Z., \& Ahmed, P. K. (2011). Ownership Structure, Board Governance, Dividends and Firm Value: An Empirical Examination of Malaysian Listed Firms. International Journal of Business Governance and Ethics, 6(2), 135-161. https://doi.org/10.1504/IJBGE.2011.039966

36. Wang, X., Manry, D., \& Wandler, S. (2011). The Impact of Government Ownership on Dividend Policy in China. Advances in Accounting, Incorporating Advances in International Accounting, 27(2), 366372. https://doi.org/10.1016/j.adiac.2011.08.003

37. Wiwattanakantang, Y. (1999). An Empirical Study on the Determinants of the Capital Structure of Thai Firms. Pacific-Basin Finance Journal, 7(3-4), 371-403.

38. Yusof, Y., \& Ismail, S. (2016). Determinants of Dividend Policy of Public Listed Companies in Malaysia. Review of International Business and Strategy, 26(1), 88-99. https://doi.org/10.1108/RIBS-022014-0030 